\title{
Enrichment of Type I Methanotrophs with nirS Genes of Three Emergent Macrophytes in a Eutrophic Wetland in China
}

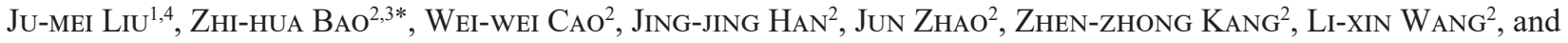 \\ Ji $\mathrm{ZHAO}^{2,3 *}$ \\ ${ }^{1}$ College of Life Sciences, Inner Mongolia University, Hohhot, 010021, China; ${ }^{2}$ Ministry of Education Key Laboratory of Ecology \\ and Resource Use of the Mongolian Plateau \& Inner Mongolia Key Laboratory of Grassland Ecology, School of Ecology and \\ Environment, Inner Mongolia University, Hohhot, 010021, China; ${ }^{3}$ Inner Mongolia Key Laboratory of Environmental Pollution \\ Control \& Waste Resource Reuse, Inner Mongolia University, Hohhot, 010021, China; and ${ }^{4}$ College of Chemistry and \\ Environmental Engineering, Chongqing Key Laboratory of Environmental Materials \& Remediation Technologies, Chongqing \\ University of Arts and Sciences, Chongqing, 402160, China
}

(Received July 24, 2019—Accepted November 25, 2019_Published online January 23, 2020)

The pmoA gene, encoding particulate methane monooxygenase in methanotrophs, and nirS and nirK genes, encoding bacterial nitrite reductases, were examined in the root and rhizosphere sediment of three common emergent macrophytes (Phragmites australis, Typha angustifolia, and Scirpus triqueter) and unvegetated sediment from eutrophic Wuliangsuhai Lake in China. Sequencing analyses indicated that 334 out of 351 cloned pmoA sequences were phylogenetically the most closely related to type I methanotrophs (Gammaproteobacteria), and Methylomonas denitrificans-like organisms accounted for $44.4 \%$ of the total community. In addition, 244 out of 250 cloned nirS gene sequences belonged to type I methanotrophs, and $31.2 \%$ of nirS genes were the most closely related to paddy rice soil clone SP-2-12 in Methylomonas of the total community. Three genera of type I methanotrophs, Methylomonas, Methylobacter, and Methylovulum, were common in both pmoA and nirS clone libraries in each sample. A quantitative PCR (qPCR) analysis demonstrated that the copy numbers of the nirS and nirK genes were significantly higher in rhizosphere sediments than in unvegetated sediments in $P$. australis and T. angustifolia plants. In the same sample, the nirS gene copy number was significantly higher than that of nirK. Furthermore, type I methanotrophs were localized in the root tissues according to catalyzed reporter deposition-fluorescence in situ hybridization (CARD-FISH). Thus, nirS-carrying type I methanotrophs were enriched in macrophyte root and rhizosphere sediment and are expected to play important roles in carbon/nitrogen cycles in a eutrophic wetland.

Key words: emergent macrophytes, root-associated Type I methanotrophs, denitrifiers, eutrophic wetland, CARD-FISH

Eutrophication is a serious issue in major aquatic ecosystems worldwide. The control of increasing eutrophication and improvements in water quality continue to be a major global challenge (Ansari et al., 2011). Aquatic macrophytes are known to play important roles in improving water quality (Dhote and Dixit, 2009) by removing considerable amounts of nitrogen and phosphorus from eutrophic bodies of water (Zheng et al., 2018). In addition, the rate of methane $\left(\mathrm{CH}_{4}\right)$ emission was found to be higher from strongly eutrophic ponds than from weakly eutrophic ponds (Merbach et al., 1996), and this was attributed to anoxia in eutrophic lakes favoring the production of $\mathrm{CH}_{4}$ (Liikanen and Martikainen, 2003). Phragmites spp., Typha spp., and Scirpus spp. are three common emergent types of macrophyte vegetation that are distributed worldwide (Vymazal, 2013), and mediate $\mathrm{CH}_{4}$ emissions from wetlands to the atmosphere (Grünfeld and Brix, 1999). The root zone (root and rhizosphere sediment) of wetland plants is under aerobic conditions (Armstrong et al., 2000) and allows the growth of aerobic methanotrophs (Type I and Type II) that utilize methane and methanol as their sole carbon and

\footnotetext{
* Corresponding authors.

E-mail: zhihua_bao@imu.edu.cn (Zhihua Bao)

andndzj@imu.edu.cn (Ji Zhao);

Tel: +86-471-499-1469; Fax: +86-471-499-1436.
}

energy sources (Hanson and Hanson, 1996). Previous studies suggested that methylotrophic bacteria and other bacterial groups live in the root zones of Phragmites australis and Typha latifolia (Chen et al., 2012; Fausser et al., 2012); however, it currently remains unclear whether differences exist in the community structure of root-associated methanotrophs among plant species, and how these methanotrophs are distributed in the root tissues of macrophytes has not yet been clarified.

Aerobic methanotrophs form an important bridge between the global carbon and nitrogen cycles, a relationship that is impacted by nitrogen deposition and deficiency (Bodelier and Laanbroek, 2004; Stein and Klotz, 2011; Bao et al., 2014b; Ikeda et al., 2014). The findings of metaproteomic analyses suggest that methane oxidation and nitrogen fixation under low-nitrogen conditions occur inside and on the surface of rice roots via type II methanotrophs, including Methylosinus spp. (Bao et al., 2014a; Minamisawa et al., 2016). However, type I methanotrophs have been the main group detected on the surface of aquatic plants (Yoshida et al., 2014), and they predominate in environments with high nitrogen loads (Beck et al., 2013). In recent years, the role of aerobic methanotrophs in mediating the nitrogen cycle, either indirectly or directly, has been attracting increasing attention. Modin et al. (2010) reported the genetic potential for denitrification by type I methanotrophs in mixed culture 
biofilms in membrane biofilm reactors. Stein and Klotz, (2011) inferred a genome inventory for the denitrifying pathway in methanotrophic isolates. Furthermore, the denitrification activity of individual type I methanotrophic isolates was reported by Kits et al. (2015a; 2015b). Thus, aerobic methanotrophs employ two processes for denitrification: 1) two strains (i.e. Methylomonas denitrificans strain FJG1 and Methylomicrobium album strain BG8) perform direct denitrification under anoxic conditions in single cells (Kits et al., 2015a; 2015b); and 2) aerobic methanotrophs and denitrifiers, which form consortia, also utilize methane as an external carbon source for denitrification via the aerobic methane oxidation coupled to denitrification (AME-D) process (Zhu et al., 2016). In both cases, aerobic methanotrophs appear to provide electron donors to the denitrification reaction. Although type I methanotrophs have been detected as the dominant group on aquatic plant surfaces, the genetic potential for the denitrification of methanotrophs in natural wetlands/ecosystems has not yet been examined in detail.

Denitrification is a beneficial process in the eutrophication aquatic system. Conventional primers for nirS and nirK genes (encoding nitrite reductase enzymes) that have some limitations in detecting diverse nirS/nirK-type environmental denitrifiers have been reported. The Methylomonas, Methylobacter, Methylosarcina, Methylomicrobium, and Methylovulum genera of Type I methanotrophs possess functional denitrification genes, including nirS or nirK (Stein and Klotz, 2011; Padilla et al., 2017). Methanotrophic denitrifiers from paddy soil have been detected using primers, including the primer set nirSC2F/nirSC2R (Wei et al., 2015). These primers are expected to promote the detection of methanotrophic denitrifiers in wetland ecosystems, including macrophytes.

Wuliangsuhai (WLSH) Lake is located near the city of Bayannur in the Inner Mongolia Autonomous Region in China. This lake is the largest freshwater lake in the Yellow River watershed; it is a rare, large-scale, shallow lake and grass wetland in this arid region. It has important ecological functions that maintain water resources, regulate the floods and droughts associated with an arid climate, and provide high biological diversity as a Ramsar site (Borruso et al., 2017). The lake recently became eutrophic after receiving large volumes of irrigation drainage water as well as municipal and industrial wastewater with high nitrogen and phosphorus contents from the Hetao Basin (Wu et al., 2017). Phragmites australis (common reed), Typha angustifolia (narrow leaf cattail), and Scirpus triqueter (bulrush) are the dominant macrophytes of WLSH (Duan et al., 2005). Many studies have examined microorganisms in their rhizosphere sediments, including the methylotroph- and heterotrophmediated processes of carbon and other element cycles (Borruso et al., 2017). However, few studies have focused on the characteristics of methanotrophic communities in the roots of macrophytes or on denitrification by aerobic methanotrophs themselves in natural wetlands.

In the present study, we (i) examined the abundance and diversity of methanotrophs and denitrifying bacteria in the root zones of three emergent macrophytes, P. australis, T. angustifolia, and $S$. triqueter, as well as plant-free sediment from WLSH, a eutrophic wetland; (ii) identified which methanotroph groups had genetic potential for denitrification; and (iii) clarified the localization of methanotrophs in the root tissues of these three macrophytes.

\section{Materials and Methods}

Macrophyte roots, sediment, and water sampling and an analysis of physicochemical properties

Three plants each of $P$. australis (PA), T. angustifolia (TA), and $S$. triqueter (ST) were collected along with soil blocks from the littoral wetland of WLSH Lake (latitude $40^{\circ} 47^{\prime}-41^{\circ} 03^{\prime} \mathrm{N}$, longitude $\left.108^{\circ} 43^{\prime}-108^{\circ} 57^{\prime} \mathrm{E}\right)$ during the growing season on July $15^{\text {th }}, 2015$ (Fig. 1). Plant roots and rhizosphere sediments were sampled according to a previous study (Kimura, 2004). Briefly, after the plants with soil blocks were sampled, soil blocks including plants were divided vertically into two equal parts to collect the roots. Some of the exposed roots were carefully picked from the plants using sterilized forceps and placed into a 50-mL centrifuge tube containing sterile water. Rhizosphere sediment samples were obtained before and after sonication (5-10 min). After the rhizosphere sediment was removed, the root samples were transferred to new centrifuge tubes $(50 \mathrm{~mL})$ containing sterile water and centrifuged at $8,000 \times g$ at $4^{\circ} \mathrm{C}$ for $10 \mathrm{~min}$. All samples were stored at $-80^{\circ} \mathrm{C}$ for later molecular analyses.

Unvegetated sediment $(\mathrm{S})$ was sampled in triplicate from depths of 10-20 cm along with water from non-vegetated areas (Fig. 1). Sediment cores were packed in sterile plastic bags and transported immediately to the laboratory in an ice-cooled box. Sediment samples were air-dried at room temperature and passed through a $2-\mathrm{mm}$ sieve for the analysis of physicochemical properties, including $\mathrm{pH}$, electrical conductivity (EC), total organic carbon (TOC), total nitrogen (TN), total phosphorus (TP), nitrate nitrogen $\left(\mathrm{NO}_{3}{ }^{-} \mathrm{N}\right)$, and ammonium nitrogen $\left(\mathrm{NH}_{4}^{+}-\mathrm{N}\right)$; the same properties were measured in water samples. Soil $\mathrm{pH}$ was assessed using a $\mathrm{pH}$ meter (HQ40D; Hach) in a 1:2.5 (w/v) suspension in ultrapure water. EC was measured in a soil-water suspension $(1: 2.5[\mathrm{w} / \mathrm{v}])$ using a conductivity meter (Leici DDS-307), and this was used to evaluate salinity (Wollenhaupt et al., 1986). TOC was assessed by dichromate oxidation. TN was measured using the Kjeldahl method. TP was measured using the ammonium molybdate spectrophotometric method. $\mathrm{NO}_{3}{ }^{-}-\mathrm{N}$ content was assessed by UV spectrophotometry, and $\mathrm{NH}_{4}{ }^{+}-\mathrm{N}$ content was measured by indophenol blue colorimetry (Nelson and Sommers, 1982; Bao, 2000).

\section{Nucleic acid extraction}

Genomic DNA was extracted from $0.5-0.8 \mathrm{~g}$ of sediment or root samples using the Fast DNA SPIN Kit for Soil (MP Biomedicals) according to the manufacturer's protocol. Regarding root samples, frozen tissues were ground into a powder using a mortar and pestle under liquid nitrogen before DNA extraction. DNA concentrations were quantified using a NanoPhotometer P-Class P-330C instrument (IMPLEN). Extracted DNA was immediately stored at $-20^{\circ} \mathrm{C}$.

\section{Clone library construction and phylogenetic analysis}

Clone libraries were constructed for roots and sediments using the primer sets $\mathrm{A} 189 \mathrm{~F} / \mathrm{mb} 661 \mathrm{R}$ for the pmoA gene (Costello and Lidstrom, 1999) and nirSC2F/nirSC2R for the nirS gene (Wei et al., 2015) (Table S3). PCR amplification was performed with $50-\mu \mathrm{L}$ mixtures in $0.2-\mathrm{mL}$ tubes using a Mastercycler (Eppendorf). The reaction mixtures included $5.0 \mu \mathrm{L} 10 \times$ PCR buffer (plus $\mathrm{Mg}^{2+}$ ), $4.0 \mu \mathrm{L} 250 \mathrm{mM}$ each dNTP, $0.4 \mu \mathrm{L} 5 \mathrm{U}_{\mu} \mathrm{L}^{-1}$ Ex Taq DNA polymerase (Takara Biotech) plus $1.0 \mu \mathrm{L}$ containing $10 \mathrm{mM}$ of each primer and $1.0 \mu \mathrm{L}$ bovine serum albumin (BSA; Amesco; $\left.20 \mathrm{mg} \mathrm{mL}^{-1}\right)$. BSA was added to reduce inhibition by humic substances (Kreader, 1996). Amplification was performed with an ini- 


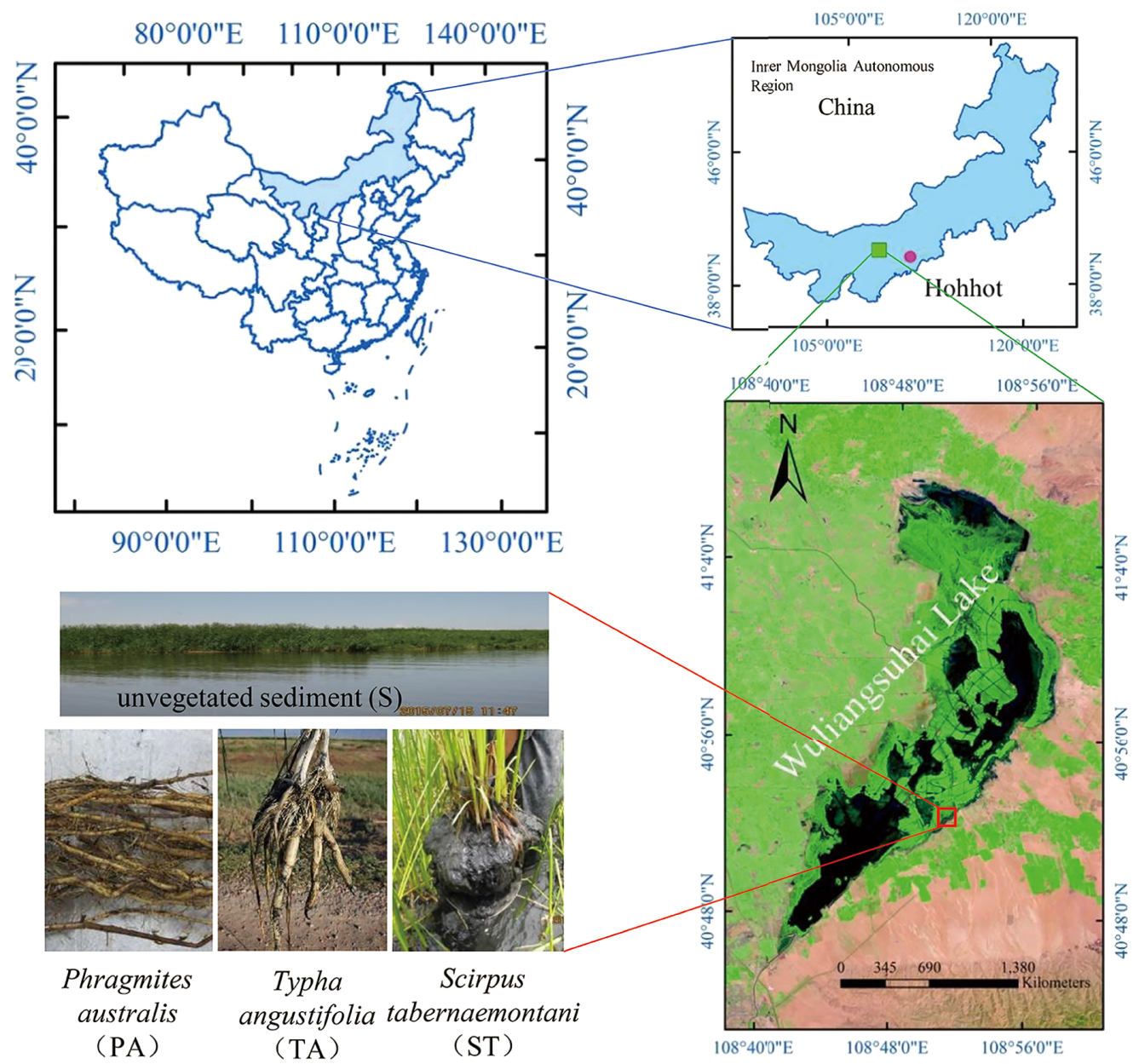

Fig. 1. Sampling site diagram of three macrophytes and unvegetated sediment from the Wuliangsuhai wetland.

tial denaturation step at $95^{\circ} \mathrm{C}$ for 3 min followed by 35 cycles at $95^{\circ} \mathrm{C}$ for $1 \mathrm{~min}, 55^{\circ} \mathrm{C}$ for $1 \mathrm{~min}$, and $72^{\circ} \mathrm{C}$ for $40 \mathrm{~s} \mathrm{(for} \mathrm{pmoA),} \mathrm{or}$ at $95^{\circ} \mathrm{C}$ for $10 \mathrm{~min}$, followed by 35 cycles at $95^{\circ} \mathrm{C}$ for $30 \mathrm{~s}, 56^{\circ} \mathrm{C}$ for $30 \mathrm{~s}$, and $72^{\circ} \mathrm{C}$ for $30 \mathrm{~s}$ (for nirS), with a final extension at $72^{\circ} \mathrm{C}$ for $10 \mathrm{~min}$ for both procedures. Regarding each plant species, three PCR products were mixed at equal molar ratios, and these formed a composite PCR product. Composite PCR products were then purified using a Gene JET PCR Purification Kit (Promega) and ligated into the pGEM-T Easy Vector (Promega) according to the manufacturer's instructions. All clones were sequenced by the Sanger method. Nucleic acid sequences were translated with MEGA software, version 5.2.2 (Tamura et al., 2011). After alignment, amino acid sequences were clustered into operational taxonomic units (OTUs) at $\geq 91 \%$ amino acid identity for the pmoA gene (Heyer et al., 2002) or $\geq 90 \%$ amino acid identity for the nirS gene using mothur software (Schloss et al., 2009). Diversity indices (e.g. coverage, Chao1, ACE, Shannon, and Simpson indices) were estimated by mothur. Representative sequences for each OTU were selected by mothur software by default, and these sequences were the most abundant within each OTU. Phylogenetic analyses of the representative sequences for each OTU were performed using MEGA with the neighbor-joining method. Bootstrap values were based on 1,000 replications.

\section{Quantification of $\mathrm{pmoA}$, nirS, and nirK genes}

qPCR assays were performed in 96-well polypropylene plates on a CFX Connect Optical Real-Time Detection System (Bio-Rad Laboratories). Regarding each plant species, DNA samples from three plants, serving as three biological replicates, were used for qPCR of the target genes. Three technical replicates were run for each DNA sample. qPCR reactions were performed in $20-\mu \mathrm{L}$ reaction mixtures containing $10 \mu \mathrm{L} 2 \times$ SYBR Premix Ex Taq (Takara Biotech), $500 \mathrm{nM}$ of each primer, and 10-20 ng DNA templates. Blanks included sterile ultrapure water as the template instead of extracted sample DNA. Details on the primers used and reaction conditions for qPCR assays are provided in Table S3. We used the methanotroph-specific primer set A189F/mb661R for the pmoA gene (Costello and Lidstrom, 1999), the denitrifying bacteria primer set nirSC2F/nirSC2R for the nirS gene (Wei et al., 2015), and the primer set $\mathrm{F} 1 \mathrm{aCu} / \mathrm{R} 3 \mathrm{Cu}$ for the nirK gene (Hallin and Lindgren, 1999). All primers were purchased from Sangon Biotech.

Standard curves for qPCR assays were generated as described previously (Cai et al., 2016) and constructed using a 10-fold dilution series of plasmids harboring the target gene. Plasmids were extracted using the TIANprep Mini Plasmid Kit (Tiangen Biotech); concentrations were measured using a NanoPhotometer P-Class P-330C (IMPLEN) and used to calculate standard copy numbers. Amplification efficiency ranged between 93.1 and $97.0 \%$ for pmoA, 94.0 and $96.3 \%$ for nirS, and 90.2 and $93.2 \%$ nirK. $\mathrm{R}^{2}$ values for standard curves ranged between 0.996 and 1.000 for the three genes. A melting curve analysis was used to confirm the specific amplification of target genes and always showed a single peak.

\section{CARD-FISH}

Catalyzed reporter deposition-fluorescence in situ hybridization (CARD-FISH) is a powerful tool in modern microbial ecology and has strong signal sensitivity (Kubota, 2013). It has been used to directly detect methanotrophs in paddy soil and field-grown rice 
roots (Bao et al., 2014a; Cai et al., 2016). M. koyamae strain Fw12E-Y ${ }^{\mathrm{T}}$ (NCIMB14606) was used as a positive control. This strain was incubated in 1a medium at $30^{\circ} \mathrm{C}$ with $50 \%(\mathrm{v} / \mathrm{v})$ methane in the headspace (Ogiso et al., 2012). Thiobacillus thiooxidans (JCM 3867) was used as a negative control (Eller et al., 2001).

To detect type I methanotrophs in the root tissues of PA, TA, and ST, we used probes for M $\gamma 84$ (3'-AGCCCGCGACTGCTCACC-5') and My705 (3'-CTAGACTTCCTTGTGGTC-5') (Eller et al., 2001). These probes were labeled with horseradish peroxidase at the $5^{\prime}$ end (Japan Bio Services). Plant roots were sectioned into 2-cm-thick pieces to visualize the location of type I methanotrophs. CARD-FISH analyses were performed as previously described (Bao et al., 2014a), with minor modifications. Briefly, endogenous peroxidases were inactivated with $1.2 \% \mathrm{H}_{2} \mathrm{O}_{2}$ in methanol at room temperature (RT) for 60 min instead of $0.15 \% \mathrm{H}_{2} \mathrm{O}_{2}$ in methanol for $30 \mathrm{~min}$ as described previously.

We used an epifluorescence microscope (Ci-L; Nikon) for microscopic observations and image acquisition. To visualize $M$. koyamae strain Fw12E-Y ${ }^{\mathrm{T}}$, we counterstained samples with 4',6diamidino-2-phenylindole (DAPI; $1 \mu \mathrm{g} \mathrm{mL}^{-1}$ ) at RT for $2 \mathrm{~min}$. We viewed M $\gamma 84+\mathrm{M} \gamma 705$-positive cells in the roots using a laser scanning confocal microscope (LSM 710; Carl Zeiss) and ZEN 2012 software (Carl Zeiss).

\section{Statistical analysis}

We tested for significant differences in pmoA, nirS, and nirK gene numbers by a one-way ANOVA with the least significant difference (LSD) test. We used Pearson's linear correlation to assess whether a correlation exists between pmoA and nirS gene copies. All statistical analyses were conducted using SPSS software, version 19.0 (IBM), and the significance level was $P<0.05$. We applied the chi-squared test to examine the significance of differences in the proportion of OTU or bacteria taxa between PA plants and TA or ST plants. We used Canoco software, version 4.5 (Ithaca) for the principal component analysis (PCA).

\section{Nucleotide sequence accession numbers}

All cloned sequences were deposited in the GenBank (http:// www.ncbi.nlm.nih.gov/BankIt/) nucleotide sequence database under accession numbers MG016967-MG017151 (roots), MG017152-MG017207 (unvegetated sediment), and MG017208MG017317 (rhizosphere sediments) for the pmoA gene, and MG016713-MG016823 (roots), MG016724-MG016726, MG016728-MG016752, MG016754-MG016757, and MG016760 (unvegetated sediment), and MG016861-MG016966 (rhizosphere sediments) for the nirS gene.

\section{Results}

\section{Physicochemical properties of WLSH Lake}

Samples were collected from WLSH Lake in the Inner Mongolia Autonomous Region of China (Fig. 1). The properties of water and sediment from WLSH Lake are shown in Table S1. The lake had saline-alkaline conditions, with the $\mathrm{pH}$ and $\mathrm{EC}$ of the water and sediment ranging between 9.0 and 9.3 and 1.35 and $6.25 \mathrm{ds} \mathrm{m}^{-1}$, respectively. The high concentrations of TOC (up to $27.62 \mathrm{mg} \mathrm{L}^{-1}$ in water and $18.35 \mathrm{~g} \mathrm{~kg}^{-1}$ dry weight in sediment), TP (up to $0.03 \mathrm{mg} \mathrm{L}^{-1}$ in water and $0.62 \mathrm{~g} \mathrm{~kg}^{-1}$ in sediment), TN (up to $1.87 \mathrm{mg} \mathrm{L}^{-1}$ in water and $2.60 \mathrm{~g} \mathrm{~kg}^{-1}$ in sediment), and nitrogenous compounds, particularly ammonium (up to $0.30 \mathrm{mg} \mathrm{L}^{-1}$ in water and $24.45 \mathrm{mg} \mathrm{kg}^{-1}$ dry weight in sediment) and nitrate (up to $0.19 \mathrm{mg} \mathrm{L}^{-1}$ in water and $1.28 \mathrm{mg} \mathrm{kg}^{-1}$ dry weight in sediment), in both the water and sediment samples showed that the lake was experiencing severe eutrophication.

\section{Phylogenetic diversities of methanotrophs based on the pmoA gene}

Three hundred and fifty-one pmoA sequences were used to identify aerobic methanotroph diversity in the root zones of the PA, TA, and ST plants as well as plant-free sediment. Basic information regarding the pmoA clone library is shown in Table S2. A phylogenetic analysis of all sequences revealed that the majority of sequences belonged to the type I methanotrophs of seven genera: Methylomonas, Methylobacter, Methylovulum, Methylomicrobium, Methylosarcina, Methyloglobulus, and Methylococcus (334 sequences, 95.2\%), with type II methanotrophs accounting for a minority (17 sequences, 4.8\%) (Fig. 2). Further analyses at finer levels showed that the relative abundance of Methylomonas among all samples ranged between 23.3 and $82.4 \%$. Methylomonas was clearly dominant over Methylobacter (1.6-23.3\%) and Methylovulum (0-3.3\%) (Fig. 3a). The relative abundance of Methylococcus in roots (1.8-6.4\%) was lower than that in all sediments (including rhizosphere sediments and unvegetated sediment) (6.9$20.0 \%$ ). Notably, the abundance of Methyloglobulus was higher in the root zone of PA (38.0-47.6\%) than in those of TA (10.9-13.3\%) and ST (0-1.5\%) (Fig. 3c). In contrast, Methylocystis was mainly responsible for the abundance of type II methanotrophs in the root zones of both TA (3.3$7.9 \%)$ and ST $(0-11.9 \%)$, but was not detected in the root zones of PA (0\%) (Fig. 3e).

The phylogenetic analysis revealed that the relative abundance of OTU STRS65 was higher in ST than in PA, TA, and unvegetated sediment. In contrast, OTU TAR109 was only absent in ST (Fig. 3b). These two OTUs were similar to $M$. denitrificans strain FJG1 (100\% sequence identity) (WP036280011) and Methylobacter luteus (95\% sequence identity) (WP027159170), respectively (Fig. 2). The relative abundance of OTU TAR107 among all samples ranged between 1.6 and 6.7\%; however, it was absent in the rhizosphere sediment of PA. The relative abundance of OTU PAR101 was higher in PA (34.5-44.4\%) than in TA and unvegetated sediment $(5.5-14.3 \%)$. Moreover, the relative abundance of OTU PARS3 was higher in the four sediment samples (Fig. 3d). The representative sequences of these three OTUs showed higher levels of identity than those of M. alcaliphilum (99\%) (WP01414702), Methyloglobulus morosus (96\%) (WP023494957), and Methylococcus capsulatus (95\%) (WP010961050) (Fig. 2). The representative sequence of OTU STR122 was closely related to Methylocystis parvus strain OBBP (AAA87219), with 96\% identity; this sequence was detected in TA and ST, but not in PA (Fig. 2 and 3f).

\section{Relationship of phylogenetic diversities between methanotrophs and denitrifiers based on pmoA and nirS genes}

Two hundred and fifty nirS sequences were used to identify denitrifier diversity in the root zones of PA, TA, and ST plants as well as plant-free sediment. Basic information on the nirS clone library is also shown in Table S2. The phylogenetic analysis revealed that three OTUs (STR7, PARS26, and PAR37) were abundant in all samples in the nirS gene 


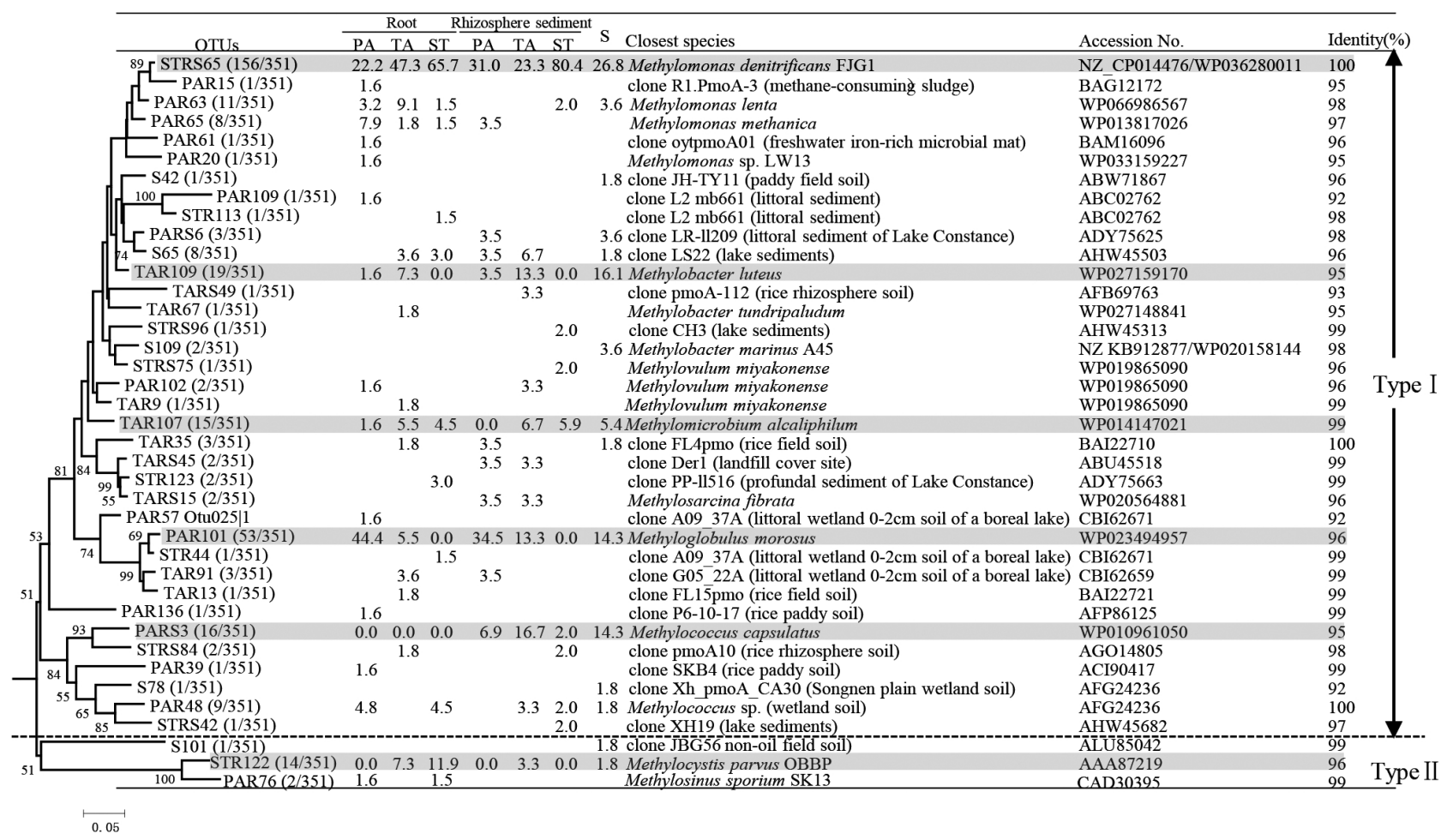

Fig. 2. Phylogenetic tree of representative OTUs ( $91 \%$ amino acid identity) based on translated pmoA gene sequences from roots and rhizosphere sediments of three plants and unvegetated sediment (PA, Phragmites australis; TA, Typha angustifolia; ST, Scirpus triqueter; R, root; RS, rhizosphere sediment; S, unvegetated sediment). The table lists the relative abundance of clones belonging to each OTU in each library and the results of BLAST searches using the representative sequences. The numbers in parentheses for each OTU indicate the number of clones out of the total number of clones. Gray shading indicates the main OTUs for roots and sediments.

clone library (Fig. 4). The representative sequences of OTUs STR7, PARS26, and PAR37 showed higher levels of identity to those of rice paddy soil clone SP-2-12 (97\%) (BAO95989), M. luteus (99\%) (WP027160273), and Methylovulum miyakonense (99\%) (WP019865396). The representative sequence of major OTU STR7 (59 out of 250 clones) was also the closest to the known bacterium M. lenta (96\%) (WP027160273) and M. denitrificans strain FJG1 (96\%) (AMK77596) (Fig. 4 and 5b).

To elucidate the relationship between methanotrophs and denitrifiers, we compared these two phylogenetic trees based on the pmoA and nirS genes. The results obtained showed that the three genera, Methylomonas, Methylobacter, and Methylovulum, were frequently detected in both the pmoA and nirS clone libraries (Fig. 5a and b).

We further calculated the relative abundance of the three most common genera in the $p m o A$ and nirS clone libraries (Fig. 6a and b). Methylomonas (34.5-82.4\% in the pmoA clone library, $57.1-100 \%$ in the nirS library) was predominant in the PA and ST root zone samples. In the TA root zone and unvegetated sediment samples, Methylomonas (23.3-58.2\% in the pmoA clone library, $30.3-41.7 \%$ in the nirS library) and Methylobacter (12.7-25.0\% in the pmoA clone library, $47.2-69.7 \%$ in the nirS library) were both dominant. In ST root zone samples, Methylobacter was less frequently detected in both clone libraries. Methylovulum $(0-3.3 \%$ in the $p m o A$ clone library and $0-13.9 \%$ in the nirS library) was detected at smaller numbers than Methylomonas and Methylobacter. Overall, clones of the pmoA and nirS genes belonging to Methylomonas,
Methylobacter, and Methylovulum of type I methanotrophs were shared by the PA, TA, and ST plants and plant-free sediment. Thus, the relative abundance of Methylomonas slightly increased from sediment to rhizosphere sediment and root, whereas that of Methylobacter decreased.

The results of PCA clearly showed a tight cluster of community structures between root and rhizosphere sediment for the same plant, whereas distinct separation was observed among the different plant taxa. Differences among plant species were more obvious than those between microhabitats (roots versus the rhizosphere) (Fig. S1a and b).

\section{Copy numbers of pmoA, nirS, and nirK genes}

To estimate the population sizes of methanotrophs and denitrifying bacteria, we performed qPCR assays with the root and rhizosphere sediment of PA, TA, and ST as well as samples of unvegetated sediment. The copy numbers $\left(\times 10^{7} \mathrm{~g}^{-1}\right.$ dry weight) of the pmoA, nirS, and nirK genes in root and sediment samples of the three plant species were calculated, and were significantly higher in rhizosphere sediment than in unvegetated sediment, except for the $p m o A$ gene in PA and TA plants $(P<0.05)$ (Table 1). Moreover, in comparisons of both nir genes in the root zones of the three plant species and in unvegetated sediment, the copy numbers of the nirS gene were significantly higher than those of the nirK gene $(P<0.05)$ (Table 1). Furthermore, Pearson's linear correlation showed that the copy numbers of the pmo $A$ gene positively correlated with those of the nirS gene among seven type samples ( $\mathrm{r}=0.741, P<0.01, n=21)$. In addition, the copy numbers of both the pmoA and nirS genes 

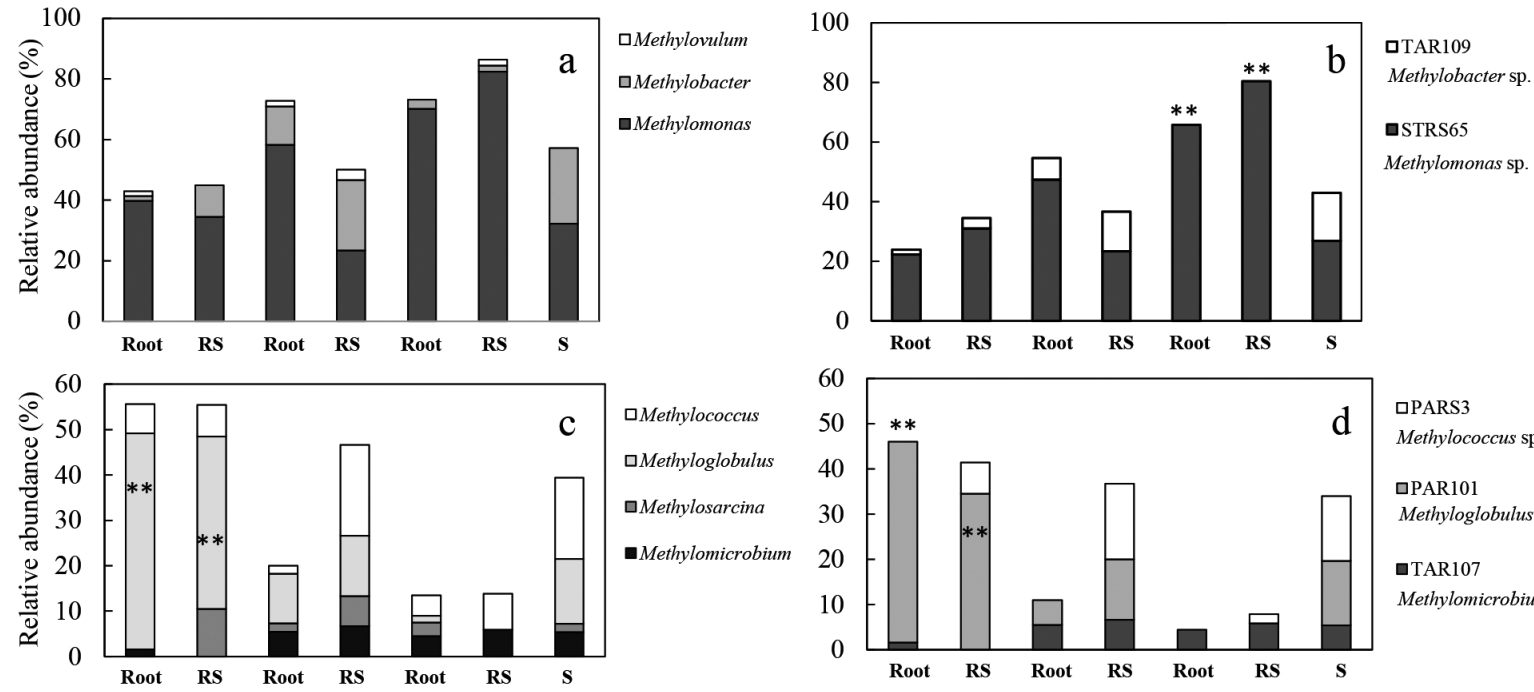

口PARS3

Methylococcus sp.

口PARI01

Methyloglobulus sp.

-TAR107

Methylomicrobium sp.
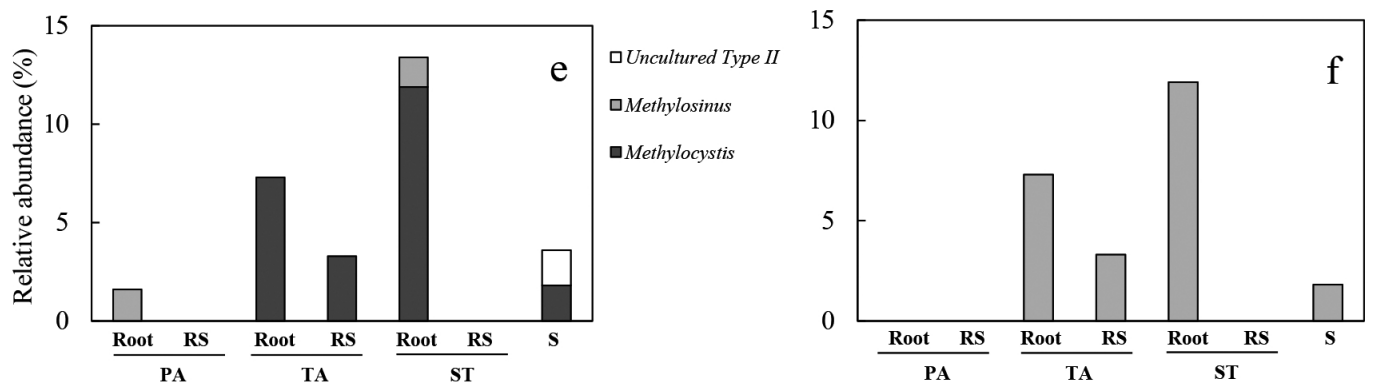

Fig. 3. Phylogenetic compositions of $p m o A$ gene clone libraries from roots and rhizosphere sediments of three plants and unvegetated sediments (PA, Phragmites australis; TA, Typha angustifolia; ST, Scirpus triqueter; RS, rhizosphere sediment; S, unvegetated sediment). (a, c, and e) Phylogenetic compositions at the genus level. (b, d, and f) Relative abundance of the main operational taxonomic units (OTUs) that occurred in the pmoA gene clone libraries. a and b: Methylomonas, Methylobacter and Methylovulum within type I methanotrophs, which were also frequently detected in the nirS gene clone libraries (Fig. 4); c and d: relative abundance of other type I methanotrophs, which were absent in the nirS gene clone libraries (Fig. 4); e and f: Type II methanotrophs, which were absent in the nirS gene clone libraries (Fig. 4). The abundance of each OTU (defined by $\geq 91 \%$ identity) corresponds to the data in Fig. 2. ** indicates a significant difference between PA plants and AT or ST plants at $P<0.05$, calculated with the chi-squared test.

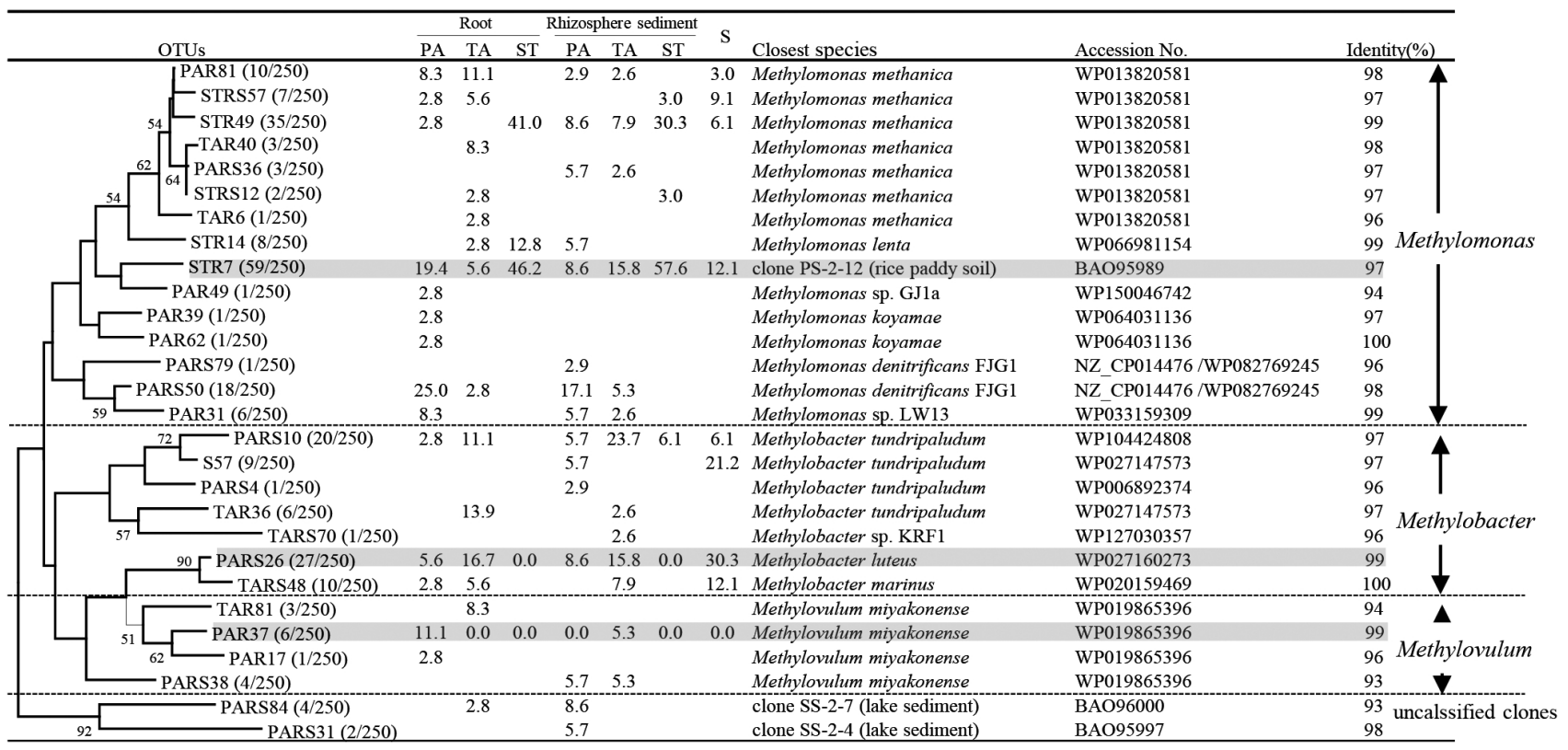

0.01

Fig. 4. Phylogenetic tree of representative OTUs (90\% amino acid identity) based on translated nirS gene clone sequences from roots and rhizosphere sediments of three plants and the unvegetated sediments. The table lists the relative abundance of clones belonging to each OTU in each library and the results of a BLAST search using representative sequences. The numbers in parentheses for each OTU indicate the number of clones out of the total clones. Gray shading indicates the main OTUs for roots and sediments. 


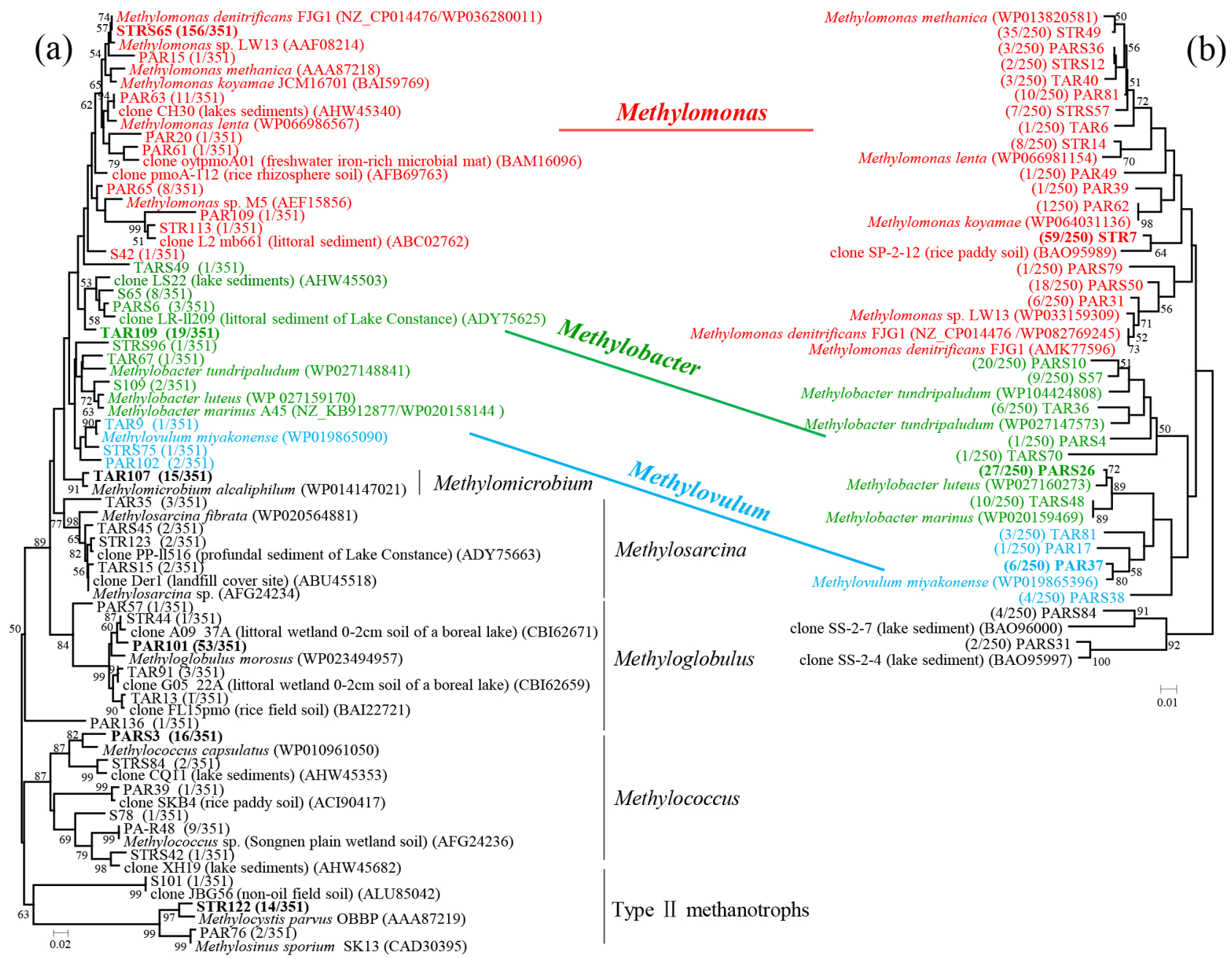

Fig. 5. Phylogenetic relationships between $p m o A$ and nirS gene clones. Phylogenetic trees were constructed based on translated (a) $p m o A$ (91\% amino acid identity) and (b) nirS (90\%) gene clone sequences from the roots and rhizosphere sediments of three plants and unvegetated sediment using the neighbor-joining method. The numbers in parentheses for each OTU indicate the number of clones out of the total clones. The accession numbers of the reference strains in the GenBank database are indicated in brackets. The bootstrap values $(\geq 50 \%)$ from 1,000 replicates are indicated next to the branches. Methylomonas (red), Methylobacter (green), and Methylovulum (blue) were commonly detected in both the pmoA and nirS gene clone libraries from all samples. Bold typeface indicates the main OTUs.

(a)

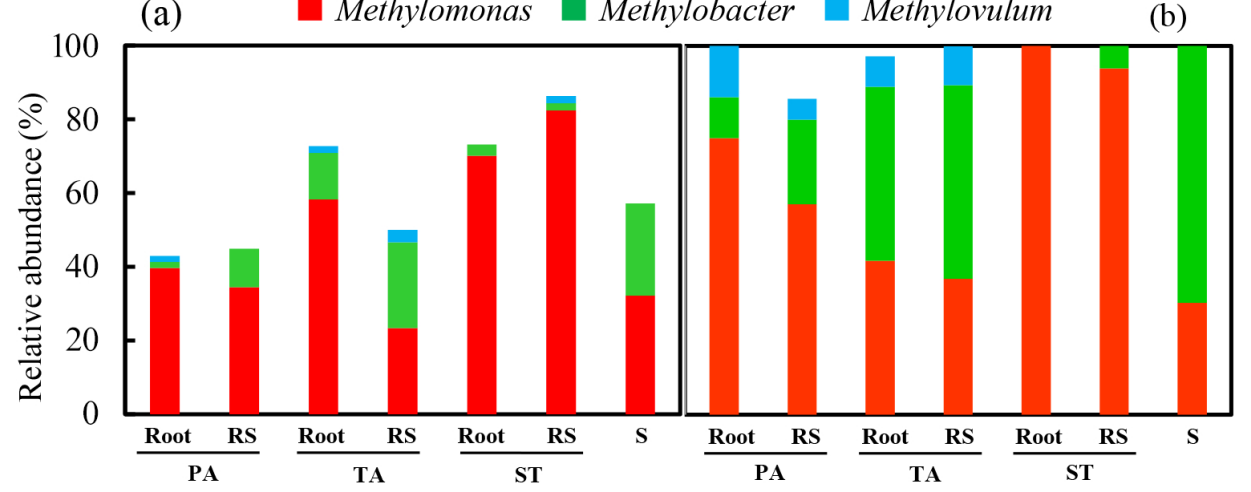

Fig. 6. Relative abundance of three common genera of Methylomonas, Methylobacter, and Methylovulum based on pmoA (A) and nirS (B) gene clone libraries in roots and rhizosphere sediment of three plants and the unvegetated sediment.

in the roots were higher in PA than in ST and TA plants (Table 1). Combined with the sequencing analysis, these results suggest that the three emergent macrophytes acted selectively on methanotrophs and methanotrophic denitrifiers, particularly Methylomonas, Methylobacter, and
Methylovulum of the type I methanotrophs that were enriched in the root zone. Furthermore, the abundance, diversities, and community structures of both groups of microbes varied among plant species. 
Table 1. Numbers of pmoA, nirS, and nirK gene copies in roots and rhizosphere sediments of three plants and unvegetated sediment

\begin{tabular}{|c|c|c|c|c|c|c|c|}
\hline \multirow{3}{*}{ Genes } & \multicolumn{7}{|c|}{ Gene abundance in ${ }^{\mathrm{a}}$} \\
\hline & \multicolumn{3}{|c|}{ Root $\left(\times 10^{7}\right)$} & \multicolumn{3}{|c|}{ Rhizosphere sediment $\left(\times 10^{7}\right)$} & \multirow{2}{*}{$\begin{array}{c}\text { Unvegetated sediment }\left(\times 10^{7}\right) \\
\mathrm{S}\end{array}$} \\
\hline & $\mathrm{PA}$ & $\mathrm{TA}$ & ST & $\mathrm{PA}$ & $\mathrm{TA}$ & ST & \\
\hline pmoA & $94.80 \pm 37.70$ & $8.38 \pm 2.44$ & $40.20 \pm 13.10$ & $2.93 \pm 2.40$ & $2.01 \pm 1.06$ & $8.65 \pm 5.97 *$ & $3.35 \pm 0.68$ \\
\hline $\operatorname{nirS}$ & $14.60 \pm 5.33^{\# \#}$ & $6.51 \pm 1.79^{\#}$ & $17.20 \pm 6.88^{\# \#}$ & $1.20 \pm 0.57^{* \#}$ & $1.27 \pm 0.10^{* \# \#}$ & $1.90 \pm 0.40 * * \#$ & $0.78 \pm 0.08^{\# \#}$ \\
\hline $\operatorname{nirK}$ & $3.60 \pm 1.12$ & $2.87 \pm 0.45$ & $2.02 \pm 0.52$ & $0.20 \pm 0.02 * *$ & $0.14 \pm 0.08 * *$ & $0.23 \pm 0.10 * *$ & $0.05 \pm 0.02$ \\
\hline
\end{tabular}

${ }^{a}$ Values are means \pm standard errors of gene abundance levels (in copies $\mathrm{g}^{-1}$ dry weight) obtained from three independent DNA extracts from the roots and rhizosphere sediments of three plants and unvegetated sediment. Significant differences between rhizosphere sediments and unvegetated sediment are indicated by an asterisk ( $*<0.05 ; * * P<0.01)$; significant differences between nir $S$ and nirK genes in the same sample are indicated by a pound sign ( ${ }^{P}<0.05$; \# $\left.P<0.01\right)$. (PA, Phragmites australis; TA, Typha angustifolia; ST, Scirpus triqueter; R, root; RS, rhizosphere sediment; $S$, unvegetated sediment).

\section{Localization of type I methanotrophs in roots of three plant species}

To validate our probe, dye, and method, we used type I methanotroph strain M. koyamae Fw12E-Y ${ }^{\mathrm{T}}$ (NCIMB14606) as a positive control. Clear signals showed that type I methanotrophs in 1a medium were successfully visualized by CARD-FISH (Fig. S2). These signals were not detected from strain $T$. thiooxidans, which was used as a negative control (data not shown).

We applied CARD-FISH to the root tissues of the three plant species to identify the localization of type I methanotrophs. Using this method, signals for type I methanotrophs were clearly observed not only in the vascular cylinder (Fig. 7a, b, c, j, k, l, m, n, and o), but also around the aerenchyma (Fig. 7d, e, and f) of PA and TA root tissues. CARD-FISH signals were observed in epithelial cells in the vertical sections of ST root tissues (Fig. 7g, h, and i).

\section{Discussion}

Previous studies demonstrated that the abundance of pmoA differed among various genotypes of the rice plant and also that type I methanotrophs were abundant in the roots of rice plants, most likely due to root selection ( $\mathrm{Wu}$ et al., 2009; Bao et al., 2014b). In addition, type I methanotrophs were found to be more abundant on the surfaces of aquatic plants than type II methanotrophs (Yoshida et al., 2014), which is consistent with the present results (Fig. 2 and Table 1). Moreover, many environmental factors, such as $\mathrm{pH}$ and the concentration of $\mathrm{NH}_{4}^{+}$, influence the community structure of methanotrophs. Molecular evidence has indicated that type I methanotrophs are predominant in the alkaline bodies of water and sediment (Deng et al., 2017). This phenomenon was attributed to the finding that some groups of type I methanotrophs were more likely to reside in saline-alkaline environments (Deng et al., 2017). A previous study suggested that an increase in $\mathrm{NH}_{4}{ }^{+}$exerted positive effects on type I members (Mohanty et al., 2006; Yang et al., 2016), whereas type II members were dominant under nitrogen-limited conditions (Graham et al., 1993). WLSH Lake, the location of this study, is a eutrophic alkaline wetland with rising salinity (Table S1), and, thus, may favor the predominance of type I methanotrophs in the root zone of wetland-grown macrophytes (Fig. 2).

nirs gene clones were frequently detected as Methylomonas, Methylobacter, and Methylovulum (Fig. 5a and $b$ ). These results support previous findings indicating that $M$. denitrificans, M. methanica, M. lenta, M. koyamae, M. luteus, and M. miyakonense possess functional denitrification genes, including nirS (Ren et al., 2000; Hoefman et al., 2014; Padilla et al., 2017). However, Methyloglobulus, Methylococcus, and Methylomicrobium were not detected with the nirS primer because these methanotrophs do not possess the nirS gene (Padilla et al., 2017) or they were present, but below the level of detection in plant roots.

A distinct separation was found in the community structures of denitrifying methanotrophs among the PA, TA, and ST plants based on PCA (Fig. S1), which is consistent with previous findings showing that plant species affect the microbial community structure in the rhizosphere (Berg and Smalla, 2009). Furthermore, the abundance of nirS genes showed that genetic potential was an effective indicator for potential denitrification activity in the roots, and the expression of these genes differed between wetland plant species (Hallin et al., 2015). These differences may be due to differences in root exudates, radial oxygen loss (ROL) rates, and oxygen availability among plant species, which may affect the rhizobacterial community composition and abundance (Calhoun and King, 1997; Wang et al., 2018).

Methane oxidation by aerobic methanotrophs generally occurs in aerobic environments; however, anaerobic and microaerobic conditions are required for denitrification. Rahalkar et al. (2009) reported that type I methanotrophs outnumbered type II methanotrophs in anoxic lake sediment by a factor of at least four. Type I methanotrophs were found to be more abundant than type II methanotrophs in the root tissues of rice plants, and this difference was more likely to be related to oxygen concentrations (Wu et al., 2009). Coincidentally, the same finding was reported for the response of pure cultures of type I and II methanotrophs to oxygen concentrations in culture experiments (Graham et al., 1993). In the present study, signals from type I methanotrophs were visualized in situ in roots using CARD-FISH, as well as in the epidermal cell walls of S. triqueter and around the vascular cylinders of $P$. australis and $T$. angustifolia (Fig. 7). However, Armstrong et al. (2010) found that oxygen concentrations at the epidermal/hypodermal cylinder (2 $\mathrm{kPa})$ were lower than those in the root center $(>12 \mathrm{kPa})$ in emergent macrophytes, such as $P$. australis. Kits et al. (2015b) reported that methane-dependent $M$. denitrificans strain FJG1 simultaneously performed methane oxidation and denitrification under hypoxia $\left(\mathrm{O}_{2}\right.$ concentration of $1.5 \%$ ). Therefore, denitrification and $\mathrm{CH}_{4}$ oxidation may 


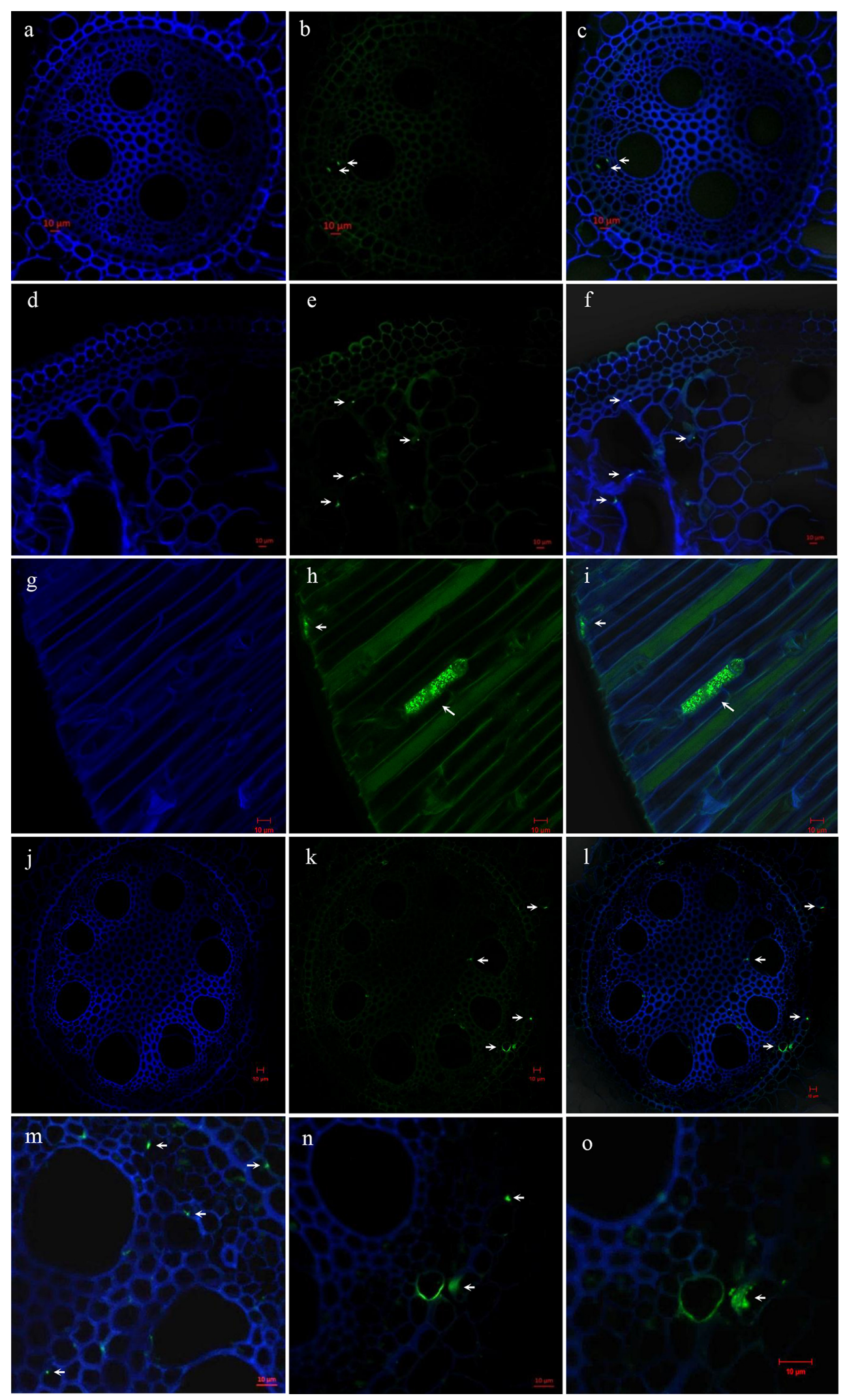

Fig. 7. Catalyzed reporter deposition-fluorescence in situ hybridization (CARD-FISH) detection of type I methanotrophs in roots of three macrophytes by confocal laser scanning microscopy. a-c, Cross-sections of the stele of a PA root; $\mathrm{d}-\mathrm{f}$, cross-sections of the aerenchyma of a PA root; $\mathrm{g}-\mathrm{i}$, vertical sections of the ST root; $\mathrm{j}-\mathrm{o}$, cross-sections of the stele of a TA root. a-i $(\times 40) ; \mathrm{j}-1(\times 20)$; $\mathrm{m}$ and $\mathrm{n}(\times 63)$; o $(\times 100)$; $\mathrm{a}, \mathrm{d}, \mathrm{g}$, and j: autofluorescence of the cell wall of roots (blue); b, e, h, and k: Alexa Fluor 488 of the M $\gamma 705+\mathrm{M} \gamma 84$ probe (green); c, f, i, 1, m, n, and o: their overlay. White arrows indicate the detected type I methanotrophs. (PA, Phragmites australis; TA, Typha angustifolia; ST, Scirpus triqueter). 
mainly occur in the epidermis rather than in the vascular cylinder of the roots in type I methanotrophs. To elucidate the underlying mechanisms in more detail, a metagenomic and/or metaproteomic analysis of root-associated microorganisms is needed in order to clarify whether type I methanotrophs play an important role in methane oxidation and denitrification. Furthermore, it will be crucial to characterize the physiological activities of Methylomonas, Methylobacter, and Methylovulum isolates from wetland plants in the future.

In summary, we herein provide the first dataset for the abundance, diversity, and localization of root-associated methanotrophs and denitrifiers in three common emergent macrophytes (P. australis, . angustifolia, and S. triqueter) in an important eutrophic wetland in northern China. The numbers of nirS and nirK gene copies were higher in rhizosphere sediment than in unvegetated sediment, suggesting that the presence of macrophytes increased the abundance of both groups of microbes over their levels in plant-free sediments. The abundance and diversities of both groups of microbes varied among plant species, with maximum numbers in P. australis, suggesting that macrophyte species had some influence on methanotroph numbers and diversity. The results of the present study emphasized that plant roots were more likely to be enriched with type I methanotrophic denitrifiers, including Methylomonas, Methylobacter, and Methylovulum, which most likely inhabit the epidermal cells, aerenchyma, and vascular bundles of root tissues of three emergent macrophytes due to root selection and environmental selection via excessive nitrogen input and salinealkaline conditions. The present results suggest that root zone type I methanotrophic denitrifiers are of great importance for simultaneously mediating methane emission and nitrogen removal in vegetated wetlands.

\section{Acknowledgements}

This work was supported by grants from the National Natural Science Foundation of China (No. 31160129 and No. 41563009), the Starting Funding for Scientific Research from Inner Mongolia University (21800-5145144), the Science and Technology Major Project on Lakes of Inner Mongolia (No. ZDZX2018054), and the Doctoral Innovation Fund of Inner Mongolia University, China (No. 2015 B10).

\section{References}

Ansari, A.A., Singh Gill, S., Lanza, G.R., and Walter, R. (2011) Eutrophication: Causes, Consequences and Control, vol. 2. New York, NY: Springer.

Armstrong, W., Cousins, D., Armstrong, J., Turner, D.W., and Beckett, P.M. (2000) Oxygen distribution in wetland plant roots and permeability barriers to gas-exchange with the rhizosphere: a microelectrode and modelling study with Phragmites australis. Ann Bot-London 86: 687-703.

Bao, S.D. (2000) Soil and Agricultural Chemistry Analysis, 2nd edn. Beijing, China: China Agriculture Press (in Chinese).

Bao, Z.H., Okubo, T., Kubota, K., Kasahara, Y., Tsurumaru, H., Anda, M., et al. (2014a) Metaproteomic identification of diazotrophic methanotrophs and their localization in root tissues of field-grown rice plants. Appl Environ Microbiol 80: 5043-5052.

Bao, Z.H., Watanabe, A., Sasaki, K., Okubo, T., Tokida, T., Liu, D.Y., et al. (2014b) A rice gene for microbial symbiosis, Oryza sativa $C C a M K$, reduces $\mathrm{CH}_{4}$ flux in a paddy field with low nitrogen input. Appl Environ Microbiol 80: 1995-2003.
Beck, D.A.C., Kalyuzhnaya, M.G., Malfatti, S., Tringe, S.G., del Rio, T.G., Ivanova, N., et al. (2013) A metagenomic insight into freshwater methane-utilizing communities and evidence for cooperation between the Methylococcaceae and the Methylophilaceae. PeerJ 1: e23.

Berg, G., and Smalla, K. (2009) Plant species and soil type cooperatively shape the structure and function of microbial communities in the rhizosphere. FEMS Microbiol Ecol 68: 1-13.

Bodelier, P.L.E., and Laanbroek, H.J. (2004) Nitrogen as a regulatory factor of methane oxidation in soils and sediments. FEMS Microbiol Ecol 47: 265-277.

Borruso, L., Esposito, A., Bani, A., Ciccazzo, S., Papa, M., Zerbe, S., and Brusetti, L. (2017) Ecological diversity of sediment rhizobacteria associated with Phragmites australis along a drainage canal in the Yellow River watershed. J Soils Sediments 17: 253-265.

Cai, Y.F., Zheng, Y., Bodelier, P.L.E., Conrad, R., and Jia, Z.J. (2016) Conventional methanotrophs are responsible for atmospheric methane oxidation in paddy soils. Nat Commun 7: 11728.

Calhoun, A., and King, G.M. (1997) Regulation of root-associated methanotrophy by oxygen availability in the rhizosphere of two aquatic macrophytes. Appl Environ Microbiol 63: 3051-3058.

Chen, W.M., Tang, Y.Q., Mori, K., and Wu, X.L. (2012) Distribution of culturable endophytic bacteria in aquatic plants and their potential for bioremediation in polluted waters. Aquat Biol 15: 99-110.

Costello, A.M., and Lidstrom, M.E. (1999) Molecular characterization of functional and phylogenetic genes from natural populations of methanotrophs in lake sediments. Appl Environ Microbiol 65: 50665074.

Deng, Y., Liu, Y., Dumont, M., and Conrad, R. (2017) Salinity affects the composition of the aerobic methanotroph community in alkaline lake sediments from the Tibetan Plateau. Microb Ecol 73: 101-110.

Dhote, S., and Dixit, S. (2009) Water quality improvement through macrophytes-a review. Environ Monit Assess 152: 149-153.

Duan, X.N., Wang, X.K., Mu, Y.J., and Ouyang, Z.Y. (2005) Seasonal and diurnal variations in methane emissions from Wuliangsu Lake in arid regions of China. Atmos Environ 39: 4479-4487.

Eller, G., Stubner, S., and Frenzel, P. (2001) Group-specific 16S rRNA targeted probes for the detection of type I and type II methanotrophs by fluorescence in situ hybridisation. FEMS Microbiol Lett 198: 9197.

Fausser, A.C., Hoppert, M., Walther, P., and Kazda, M. (2012) Roots of the wetland plants Typha latifolia and Phragmites australis are inhabited by methanotrophic bacteria in biofilms. Flora (Jena) 207: 775-782.

Graham, D.W., Chaudhary, J.A., Hanson, R.S., and Arnold, R.G. (1993) Factors affecting competition between type I and type II methanotrophs in two-organism, continuous-flow reactors. Microb Ecol 25: 1-17.

Grünfeld, S., and Brix, H. (1999) Methanogenesis and methane emissions: effects of water table, substrate type and presence of Phragmites australis. Aquat Bot 64: 63-75.

Hallin, S., and Lindgren, P.E. (1999) PCR detection of genes encoding nitrite reductase in denitrifying bacteria. Appl Environ Microbiol 65 : $1652-1657$.

Hallin, S., Hellman, M., Choudhury, M.I., and Ecke, F. (2015) Relative importance of plant uptake and plant associated denitrification for removal of nitrogen from mine drainage in sub-arctic wetlands. Water Res 85: 377-383.

Hanson, R.S., and Hanson, T.E. (1996) Methanotrophic bacteria. Microbiol Rev 60: 439-471.

Heyer, J., Galchenko, V.F., and Dunfield, P.F. (2002) Molecular phylogeny of type II methane-oxidizing bacteria isolated from various environments. Microbiology 148: 2831-2846.

Hoefman, S., Heylen, K., and De Vos, P. (2014) Methylomonas lenta sp. nov., a methanotroph isolated from manure and a denitrification tank. Int J Syst Evol Microbiol 64: 1210-1217.

Ikeda, S., Sasaki, K., Okubo, T., Yamashita, A., Terasawa, K., Bao, Z.H., et al. (2014) Low nitrogen fertilization adapts rice root microbiome to low nutrient environment by changing biogeochemical functions. Microbes Environ 29: 50-59.

Kimura, M. (2004) Counting and isolation of rhizosphere microorganism. In Experimental Methods in Soil Microbiology. Japanese Society of Soil Microbiology, 3rd edn. Tokyo: Yokendo, pp. 125-371. 
Kits, K.D., Campbell, D.J., Rosana, A.R., and Stein, L.Y. (2015a) Diverse electron sources support denitrification under hypoxia in the obligate methanotroph Methylomicrobium album strain BG8. Front Microbiol 6: 1072.

Kits, K.D., Klotz, M.G., and Stein, L.Y. (2015b) Methane oxidation coupled to nitrate reduction under hypoxia by the Gammaproteobacterium Methylomonas denitrificans, sp. nov. type strain FJG1. Environ Microbiol 17: 3219-3232.

Kreader, C.A. (1996) Relief of amplification inhibition in PCR with bovine serum albumin or T4 gene 32 protein. Appl Environ Microbiol 62: 1102-1106.

Kubota, K. (2013) CARD-FISH for environmental microorganisms: technical advancement and future applications. Microbes Environ 28: 3-12.

Liikanen, A., and Martikainen, P.J. (2003) Effect of ammonium and oxygen on methane and nitrous oxide fluxes across sediment-water interface in a eutrophic lake. Chemosphere 52: 1287-1293.

Merbach, W., Augustin, J., Kalettka, T., and Jacob, H.J. (1996) Nitrous oxide and methane emissions from riparian areas of ponded depressions of northeast Germany. J Appl Bot Food Qual 70: 134136.

Minamisawa, K., Imaizumi-Anraku, H., Bao, Z.H., Shinoda, R., Okubo, T., and Ikeda, S. (2016) Are symbiotic methanotrophs key microbes for $\mathrm{N}$ acquisition in paddy rice root? Microbes Environ 31: 4-10.

Modin, O., Fukushi, K., Nakajima, F., and Yamamoto, K. (2010) Nitrate removal and biofilm characteristics in methanotrophic membrane biofilm reactors with various gas supply regimes. Water Res 44: 8596.

Mohanty, S.R., Bodelier, P.L.E., Floris, V., and Conrad, R. (2006) Differential effects of nitrogenous fertilizers on methane-consuming microbes in rice field and forest soils. Appl Environ Microbiol 72: 1346-1354.

Nelson, D.W., and Sommers, L.E. (1982) Total carbon, organic carbon, and organic matter. In Methods of Soil Analysis. Page, A.L. (ed.). Madison, WI: American Society of Agronomy and Soil Science Society of America, pp. 539-579.

Ogiso, T., Ueno, C., Dianou, D., Huy, T.V., Katayama, A., Kimura, M., and Asakawa, S. (2012) Methylomonas koyamae sp. nov., a type I methane-oxidizing bacterium from floodwater of a rice paddy field. Int J Syst Evol Microbiol 62: 1832-1837.

Padilla, C.C., Bertagnolli, A.D., Bristow, L.A., Sarode, N., Glass, J.B., Thamdrup, B., and Stewart, F.J. (2017) Metagenomic binning recovers a transcriptionally active gammaproteobacterium linking methanotrophy to partial denitrification in an anoxic oxygen minimum zone. Front Mar Sci 4: 23.

Rahalkar, M., Deutzmann, J., Schink, B., and Bussmann, I. (2009) Abundance and activity of methanotrophic bacteria in littoral and profundal sediments of Lake Constance (Germany). Appl Environ Microbiol 75: 119-126.
Ren, T., Roy, R., and Knowles, R. (2000) Production and consumption of nitric oxide by three methanotrophic bacteria. Appl Environ Microbiol 66: 3891-3897.

Schloss, P.D., Westcott, S.L., Ryabin, T., Hall, J.R., Hartmann, M., Hollister, E.B., et al. (2009) Introducing mothur: open-source, platform-independent, community-supported software for describing and comparing microbial communities. Appl Environ Microbiol 75: $7537-7541$.

Stein, L.Y., and Klotz, M.G. (2011) Nitrifying and denitrifying pathways of methanotrophic bacteria. Biochem Soc Trans 39: 1826-1831.

Tamura, K., Peterson, D., Peterson, N., Stecher, G., Nei, M., and Kumar, S. (2011) MEGA5: Molecular evolutionary genetics analysis using maximum likelihood, evolutionary distance, and maximum parsimony methods. Mol Biol Evol 28: 2731-2739.

Vymazal, J. (2013) Emergent plants used in free water surface constructed wetlands: A review. Ecol Eng 61: 582-592.

Wang, Q., Hu, Y.B., Xie, H.J., and Yang, Z.C. (2018) Constructed Wetlands: A review on the role of radial oxygen loss in the rhizosphere by macrophytes. Water (Basel, Switz.) 10: 678.

Wei, W., Isobe, K., Nishizawa, T., Zhu, L., Shiratori, Y., Ohte, N., et al. (2015) Higher diversity and abundance of denitrifying microorganisms in environments than considered previously. ISME J 9: $1954-1965$.

Wollenhaupt, N.C., Richardson, J.L., Foss, J.E., and Doll, E.C. (1986) A rapid method for estimating weighted soil salinity from apparent soil electrical conductivity measured with an aboveground electromagnetic induction meter. Can J Soil Sci 66: 315-321.

Wu, L., Ma, K., and Lu, Y. (2009) Rice roots select for type I methanotrophs in rice field soil. Syst Appl Microbiol 32: 421-428.

Wu, L.H., Wang, X.Y., Li, J.Y., Yu, R.H., Wang, L.X., and Zhao, J. (2017) Tag-encoded pyrosequencing analysis of bacterial communities in the sediments of a eutrophic lake on the Inner Mongolian Plateau. J Biobased Mater Bioenergy 11: 271-277.

Yang, Y.Y., Zhao, Q., Cui, Y.H., Wang, Y.L., Xie, S.G., and Liu, Y. (2016) Spatio-temporal variation of sediment methanotrophic microorganisms in a large eutrophic lake. Microb Ecol 71: 9-17.

Yoshida, N., Iguchi, H., Yurimoto, H., Murakami, A., and Sakai, Y. (2014) Aquatic plant surface as a niche for methanotrophs. Front Microbiol 5: 30.

Zheng, Y.C., Dzakpasu, M., Wang, X.C., Zhang, L., Ngo, H.H., Guo, W.S., and Zhao, Y.Q. (2018) Molecular characterization of long-term impacts of macrophytes harvest management in constructed wetlands. Bioresour Technol 268: 514-522.

Zhu, J., Wang, Q., Yuan, M., Tan, G.A., Sun, F., Wang, C., et al. (2016) Microbiology and potential applications of aerobic methane oxidation coupled to denitrification (AME-D) process: A review. Water Res 90: 203-215. 